\title{
Karayollarında Yeni Teknolojik Gelişmeler Üzerine Bir Değerlendirme
}

\author{
Kemal Armağan ${ }^{1 *}$ \\ ${ }^{1}$ Karamanoğlu Mehmetbey Üniversitesi, Mühendislik Fakültesi, İnşaat Mühendisliği Bölümü, Karaman, Türkiye (ORCID: 0000-0002-4443-0761)
}

(İlk Geliş Tarihi 1 Aralık 2019 ve Kabul Tarihi 31 Aralık 2019)

(DOI: 10.31590/ejosat.661103)

ATIF/REFERENCE: Armağan, K. (2019). The New Technological Advances in Highway Pavements: A Review. Avrupa Bilim ve Teknoloji Dergisi, (17), 1092-1096.

\section{Özet}

Yollar, sosyal faydalarla birlikte, bir toplumda ekonomik kalkınmaya ve büyümeye katkıda bulunmada önemli bir rol oynar. Bu nedenle, bir ülkenin gelişmesinde hayati rolü bulunmaktadır. Dünyada karayolu uzunluğu 16,3 milyon Km olsa da her ülkeye bağlı olarak, yeni inşaat ve bakım ihtiyacı her zaman bir zorunluluktur.

Öte yandan, küresel değişimler, asfalt endüstrisinin muaf olmadığı, sürdürülebilirlik çerçevesi içinde faaliyet göstermesi için tüm sektörleri baskı altında tutuyor. Bu nedenle karar vericiler atmosferi, insan sağlığını ve rahatlığını korumak için günlük düzenlemeler yapıyorlar. Bu koşullar altında, hükümetler ve akademisyenleri de içeren karayolu endüstrisinin tüm paydaşları, teknik iyileştirmeler ile düşük maliyetli, çevre ve insan sağllğı çözümleri arasındaki dengeyi sağlayarak, korumayı teşvik eden yeni teknikler ve materyaller aramaktadır. Herhangi bir "doğru" ürün, üretim, teknik, tesis, fon kullanımının değeri, bu bağlamda her paydaş için giderek daha önemli hale gelmektedir.

$\mathrm{Bu}$ çalışmada yol kaplamalarındaki yeni teknolojik gelişmeler dikkate alınarak, sürdürülebilirlik bakımından değerlendirilmiştir.

Anahtar Kelimeler: Asfalt kaplama, dayanıklılık, sürdürülebilirlik, teknolojik gelişmeler.

\section{A Review on New Technological Advances in Highways}

\begin{abstract}
Roads, together with social benefits, play an important role in contributing to economic development and growth in a community. For this reason, they play a vital role in national growth production. Although in the world its length is 16.3 million Km, depending on each country, the need for new construction and maintenance is always a must.

On the other hand, global changes pressure all sectors to operate within the sustainability framework, where the asphalt industry is not exempt. Also, decision-makers are issuing day-to-day regulations to protect the atmosphere and human health and relief for this reason. Under these conditions, all the stakeholders of highway pavement industry including governments and academicians are searching for new techniques and materials, promoting conservation, indicating that by balancing between technical improvements and cost-effective environmental and human health care solutions. The value of the use of any "right," product, production, techniques, facility, the fund is becoming more and more important to each stakeholder in this regard.

In this study, new technological developments in road pavements are taken into consideration and evaluated in terms of sustainability.
\end{abstract}

Keywords: Asphalt pavement, durability, sustainability, technological developments.

\footnotetext{
* Sorumlu Yazar: Karamanoğlu Mehmetbey Üniversitesi, Mühendislik Fakültesi, İnşaat Mühendisliği Bölümü, Karaman, Türkiye, ORCID: 00000002-4443-0761, kemalarmagan@kmu.edu.tr
} 


\section{Introduction}

Demand for fossil fuels is rising rapidly over time; the prospect of non-renewable energy generation needs to be halted. This overconsumption and related threats are also pressing the climate and the economy. Global energy consumption levels for non-renewable energy grew to 80 per cent in 2004 and will continue to rise over the next 20-30 years due to population growth as a critical factor (Giridiyal \& Singh, 2017). This level results in a large amount of CO emissions and greenhouse gasses being released into the atmosphere raising concerns about rising sea levels, rising mean temperatures and extreme weather conditions. Increasing energy demand would lead to an increase in the price of fossil fuels which leads to tax policies and thus to higher electricity bills for end users. The main issue is that the fossil fuels used in recent generations are exhaustible, by one definition, by one word, exhaustible (Rojey, 2009). These conditions also require new developments in transportation industry namely using roller compacted concrete, concrete pavements as an alternative material to asphalt (Calis \& Yildizel, 2019).

With the developments in materials, design methods and road construction machinery used in road construction in the world, road users, road building authorities and all remaining road industry stakeholders must keep up with the new regulations and expectations that are changing day by day. Developments in batteries, fuel cells and other energy storage technologies used in electric cars come to the forefront as solutions to reduce the dependence on fossil fuel resources in the future.

In addition, these technologies, such as autonomous vehicle technologies, vehicle-vehicle and vehicle-road communication technologies, have been added to these technological developments in the coming years. By these technological developments, a safer, reliable, predictable, controlled, integrated, effective and much more interactive road usage can be realized. In some developed countries there are some of these technologies in use but projects such as 5th Generation Road Project will combine these technologies together.

In this study, information about new technological advances in highways, the expectations of road users from the road and their expectations from their journeys are given. Also, an assessment has been made on how much advanced technology usage in new projects can meet the expectations of road users. Lastly, these technological developments have been evaluated in terms of sustainability concept, which is used frequently in improving the existing road network in developed countries.

\section{Technological Developments}

In the last century, technological developments have increased rapidly, and through extensive use of the Internet and quick access to knowledge, the rate of improvement has risen to a different level. Personal characteristics and attitudes have significantly changed due to smart technology innovations. Smart software, smartphones, smart homes and smart car technologies are becoming very popular. Such advances and their widespread use in actual life have also modified human behavior and perceptions. Recently, it is seen that governments are making technological transformations in their systems for their people, that companies are also renovating and modernizing their production systems, that the quality and quantity of their goods for the new market are becoming more and more common and significant, as is the use of capital. On the other side, all these changes should be made in the context of the sustainability strategy. From this point of view, the use of ' right ' facilities, such as goods, development, funds, techniques, etc., under the sustainability approach is becoming more and more relevant.

As stated in the IISD report of the G7 countries, a group of finance ministers and central bank governors agreed to phase out the use of oil, gas and coal by the end of 2100. A sort of agreement to seek sustainable solutions from leading countries offers a green light to major investment opportunities around the globe (Kour, 2016).

With the spread of information and technology, the role and importance of technology in our lives have started to become more apparent. Application of software's have become widely common in all engineering areas (Misir, 2018). It is one of the facts of our day, where people are used to the ease of technology and always want more, as well as the positive and negative aspects of growing the role of technology in human life.

The need for economic gain and comfort is growing, as shown in Fig 1. Like many sectors, road industry stakeholders come up with different solutions and renew themselves in accordance with these innovations. Nonetheless, technological developments often require several improvements from the road business. Some of these changes are road \& signaling will serve the car, new uses $\&$ impacts on the infrastructure have developed, need for energy \& connectivity through the infrastructure have constructed, data which is the new infrastructure actor usage have improved, and intelligent cars \& evolution of the value chain have significantly improved (Bastien, 2018). 

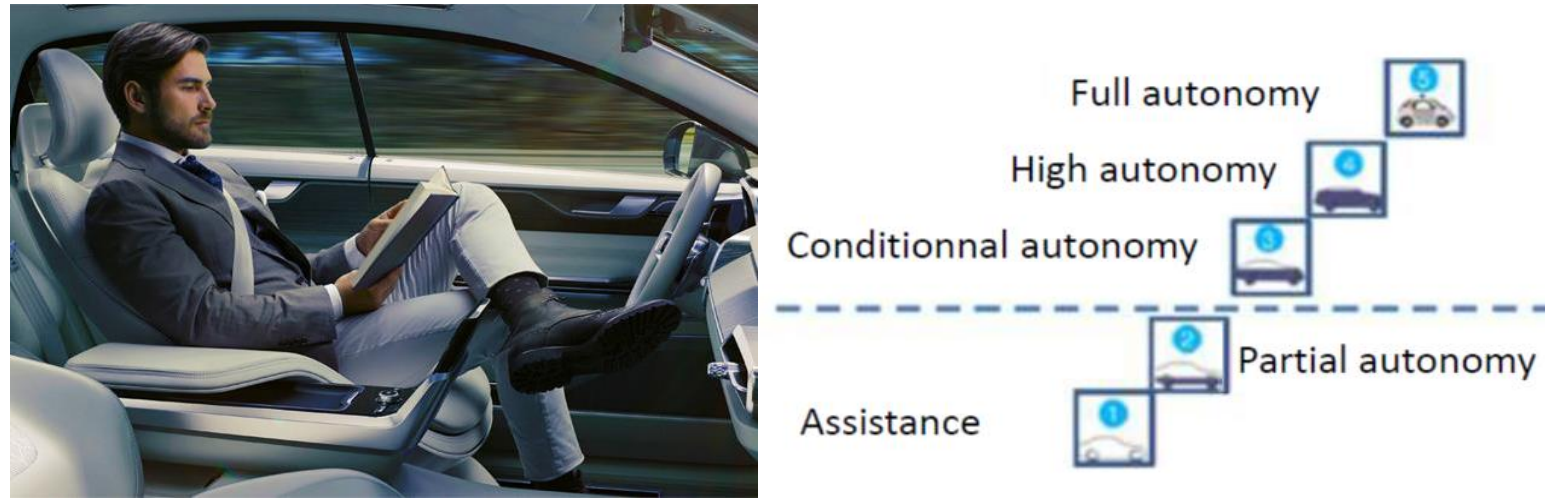

Fig.1. Smart car to a fully automatic car (Bastien, 2018).

There are two ongoing projects in Europe named "The Fabric Project" and "5th Generation Road (R5G) Project" to effectively use the roads for hybrid or electric cars and buses, as seen in Fig 2 and Fig 3(Hautière, 2018; Perrin, 2014). In Fig 2, the schematic theory of electrical infrastructure and ICT solutions relevant to the operation of an on-road dynamic inductive charging station has been demonstrated (Perrin, 2014).

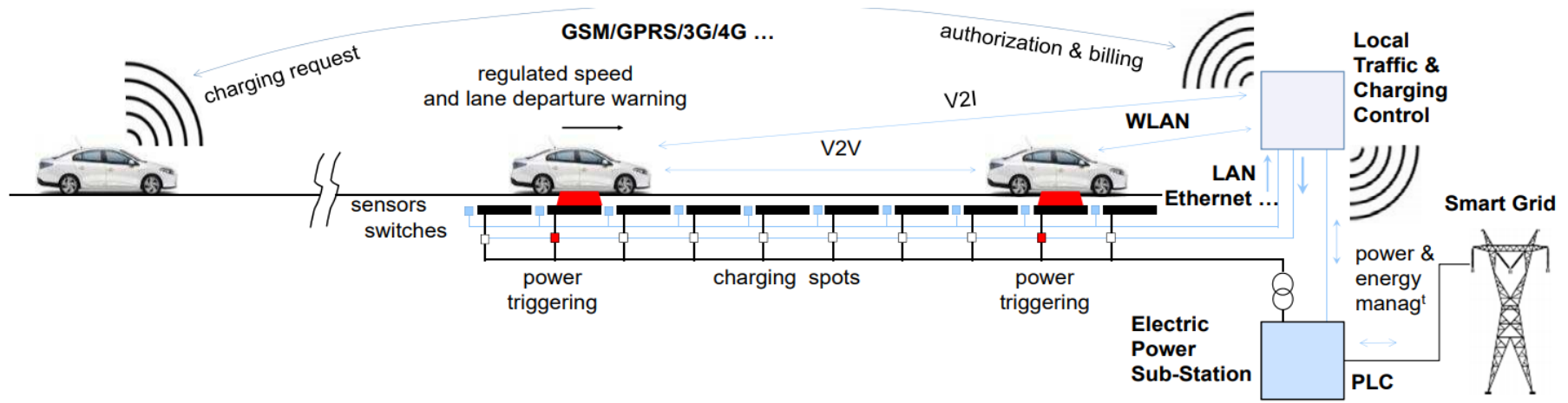

Fig.2. FABRIC smart electric car charging road EU project (Hautière, 2018).

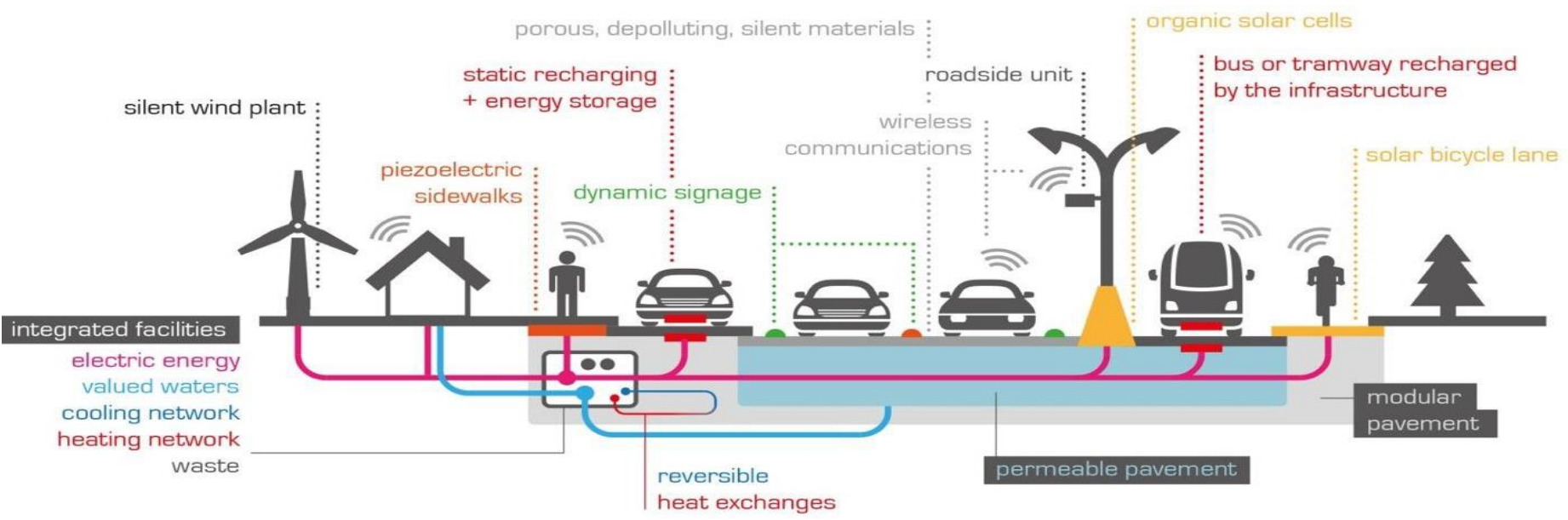

Fig.3. 5th Generation Road (R5G) Project (Hautière, 2018).

The developments like environment friendly organic resin-based roads such as Eco-Pave, dynamic paints in a pavement that can change due to whether or temperature, glowing-in-the-dark road markings, wind powered lights, wireless electric vehicle charging, solar energy roads, piezoelectric roads and wireless intelligent network have developed in past years (Metcalfe, 2012). In addition to all these developments static and dynamic charging, dynamic signage, porous, depolluting and silent material usage, organic solar cell usage and solar bicycle lane have developed. Also, modular and permeable pavement, reversible heat exchange usability has found, the electric energy, valued waters, cooling-heating networks and waste have associated in integrated facilities. Most of the developments mentioned above have combined in 5th generation roads (Hautière, 2018).

The Korea Advanced Technology Institute (KAIST) has established another advance which is a wireless powered on-line electric vehicle (OLEV). The battery in the vehicle can be remotely charged from the wireless power transmitters embedded in the road using advanced wireless power transmission technology as shown in Fig 4. Since the OLEV is a road-integrated electrical vehicle device that can remotely pick up power from the wireless power transmitters located under the lane, as can be seen in Fig. 5 , the battery life depends on the distribution of the wireless power transmitter (Jeong, Jang, \& Kum, 2014). 


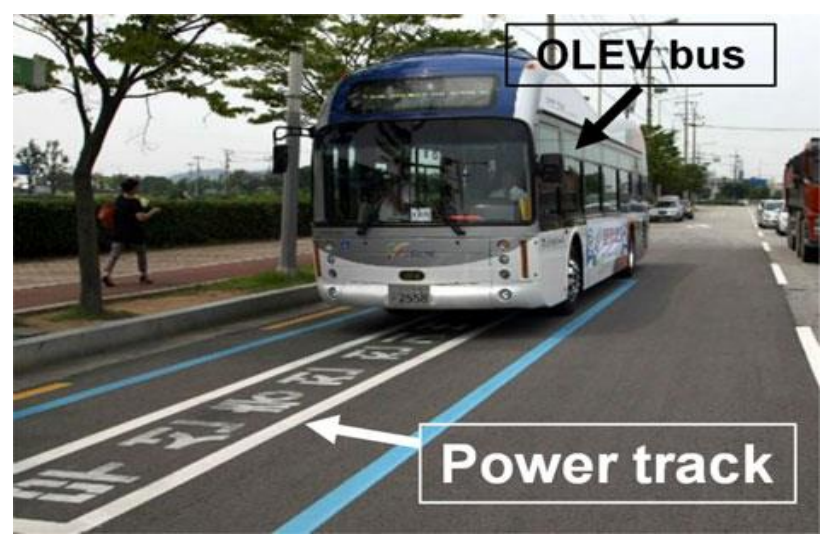

Fig. 4. OLEV bus (Jeong, Jang, \& Kum, 2015).

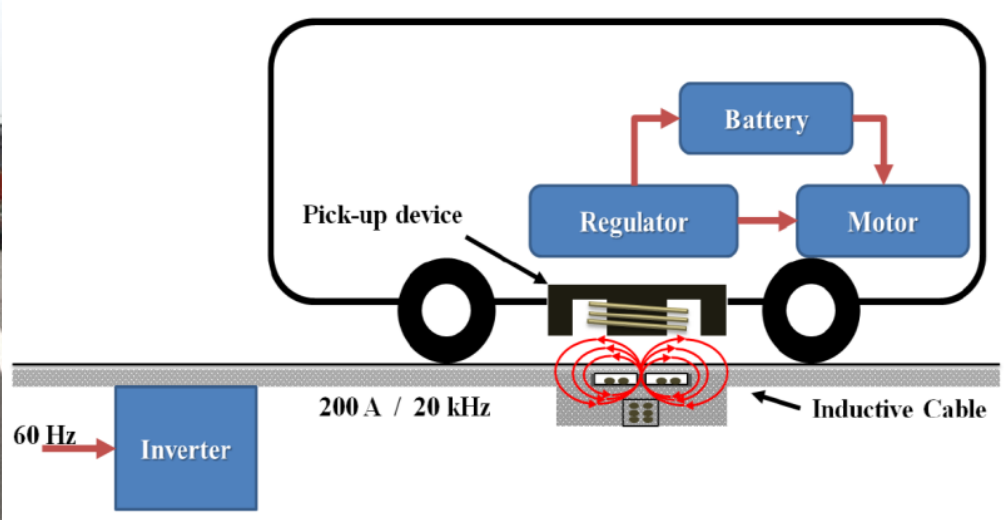

Fig. 5. Electrical charging mechanism from the road (Jeong et al., 2014).

\section{Human Needs}

In order to developments in technology, road user needs have changed and their expectations from roads have generally increased.

As far as roads and traffic are concerned, they are most likely to be concerned with issues surrounding ease of mobility, accessibility, and the quality of their journeys (PIARC, 2019). Road users need surfaces without dips, bumps, potholes, undulations or deep ruts; in other words, consistently flat asphalt surfaces with straight white lines and 'cat eyes'. The Table 1 below can be categorizing the needs of road users (Khojinian, 2018);

Table 1. The needs of road users (Khojinian, 2018; PIARC, 2019).

\begin{tabular}{|l|l|}
\hline No & The categorized need of the road user \\
\hline 1 & Improved safety further decreases in road accidents and fatalities, \\
\hline 2 & Improved traffic flow and reduced delays generally, \\
\hline 3 & Reduced congestion and improved road capacity prediction quality, \\
\hline 4 & Better surface quality, signaling and lighting, \\
\hline 5 & Better reliability of travel and better interconnecting between modes, \\
\hline 6 & Better roadside facilities, \\
\hline 7 & Better travel and less disruption in infrastructure and working areas, \\
\hline 8 & Better alignment with other roads, \\
\hline 9 & Enhanced protection for bicycles and pedestrians, \\
\hline 10 & Responding to the needs of bus and coach operators and their customers to improve access to longer distance services, \\
\hline 11 & Timely and reliable data in order to be able to make informed travel decisions for road users and the logistics sector, \\
\hline 12 & Future-proofing of new investments to ensure that projects are ready to respond to advances in vehicle and navigation \\
\hline
\end{tabular}

\section{Sustainability}

Sustainability is described as "Sustainable development is a development that meets the needs of today, without sacrificing the capacity of future generations to meet their own needs" by the World Commission on Community and Development. The term focuses on the concept of ' needs ' and the concept of limitations imposed by state-of - the-art technology and social organization on the capacity of the community to meet current and future needs (Thomas J. Van Dam, et al., 2015).

Economic deductions in investments, exchanges in social expectations, the need to comfort and safety in daily life, improved understanding of sustainability approach and such things like that have pushed people to produce innovative solutions. So, the road users, the governments and all the remaining stakeholders such as industry have effected from these technological advances.

Opportunities to increase pavement sustainability occur throughout the pavement life cycle and have the potential to deliver enormous economic, environmental and social benefits. A few examples of the advantages of being more sustainable on the three pillars 
of sustainability are reduced life-cycle costs, reduced energy usage, reduced noise pollution, improved air quality, improved water quality, improved safety, improved ride quality, conservation of resources, reduced landfill space (FHWA, 2018).

Technologies in 5th Generation Road Project such as, static recharging, organic solar cells, recharging by the infrastructure for buses and tramways, solar bicycle lanes, piezoelectric sidewalks, reversible heat exchange modules are very good usage examples of a sustainable road. When these technologies are used together, they can increase the benefits and the efficiency of energy usage. So, the energy need for the new technologies in the road can be obtained from the road and the near facilities to the road. Also, wireless communication systems can help to achieve more fluent traffic flow, so the energy consumption due to traffic congestion can decrease.

\section{Conclusions}

The place of technology and its benefits in human life is increasing very significantly. Needs from every industry are changing and this demand leads to new solutions, for example, full autonomy in cars with interactive information systems, ongoing electrical charging from roads. The RG5 project aimed to build a road-friendly approach that would encourage road innovation. There are also advances in pavement materials as well as building techniques. However, building such an eco-road system is not an individual technology. Also, it is essential to make these roads more durable so that the maintenance and repair costs of these roads are as high as the construction costs, and that the buried electronic materials can operate more efficiently without deterioration. At this point, it is thought that the developments in the new road construction techniques are becoming the foreground in the construction of more durable roads. If a comparative analysis done between human needs and technological advances the obtained results can be like below;

* The increased autonomy in vehicles and communication in car to car and car to road technology usage can decrease the road accidents and fatalities, so a safer road travel for vehicles, bicycle users and pedestrians can be provided.

* The increased wireless communication of road, vehicle and road operator can provide a fluent traffic flow, reduced congestion, reduced delays, improved road capacity prediction quality, more reliable travel, better interconnecting between other modes and more reliable data for travel decisions to road users and logistic sector.

For a sustainable road design and usage, only the road material and design method cannot be enough in the future. To design a more energy efficient road system, 5th Generation Road Project can be a leading project for future roads. In this context, along with ongoing and new researches, it is expected that different engineering branches need to work together to produce a sustainable, durable, ecofriendly road system that meets the expectations of road users. This study is thought to create an awareness about these technologies and lead to a multidisciplinary study for applied analysis.

\section{References}

Bastien, G. (2018). How will new technologies impact our roads in the future? E\&E 2018 Preparing The Asphalt Industry For The Future. Berlin.

Calis, G., \& Yıldizel, S. A. (2019). Investigation of roller compacted concrete : Literature review. 10(3), 63-74.

FHWA. (2018). Pavements Why is sustainability important in pavement systems? Why do Roads Matter? What are the Benefits of Being More Sustainable?

Giridiyal, D., \& Singh, P. (2017). Performance Analysis of Piezoelectric Materials in Energy Harvesting. 4(6), 29-34.

Hautière, N. (2018). 5th Generation Road Programmes. E\&E 2018 Preparing The Asphalt Industry For The Future.

Jeong, S., Jang, Y. J., \& Kum, D. (2014). Design optimization of the OLEV system considering battery lifetime. 2014 17th IEEE International Conference on Intelligent Transportation Systems, ITSC 2014, (May 2015), 2492-2498. https://doi.org/10.1109/ITSC.2014.6958089

Jeong, S., Jang, Y. J., \& Kum, D. (2015). Economic Analysis of the Dynamic Charging Electric Vehicle. IEEE Transactions on Power Electronics, 30(11), 6368-6377. https://doi.org/10.1109/TPEL.2015.2424712

Khojinian, A. (2018). Strategic Road Investment Plan 2020-25 and Transport Focus Road Users Survey. E\&E 2018 Preparing The Asphalt Industry For The Future. Berlin.

Kour, R. (2016). Piezoelectric Roads: Energy Harvesting Method Using Piezoelectric Technology. Innovative Energy \& Research, 5(1), 1-6. https://doi.org/10.4172/2576-1463.1000132

Metcalfe, J. (2012). 9 Technologies for Building the "Road of the Future" - CityLab. City Lab, 1-7. Retrieved from https://www.citylab.com/life/2012/12/9-technologies-building-road-future/4219/

Misir, G. (2018). Predicting the uplift capacity of vertically located two-plate anchors. Acta Geotechnica Slovenica, 15(2), 47-57. https://doi.org/10.18690/actageotechslov.15.2.47-57.2018

Perrin, J. (2014). On-Road Charging of Electric Vehicles : the Fabric Project. (April). https://doi.org/10.13140/RG.2.2.18735.94883

PIARC(World Road Association). (2019). Road Network Operations \& Intelligent Transport Systems a Guide for Practitioners!

Rojey, A. (2009). Energy \& Climate: How to Achieve a Successful Energy Transition. Energy \& Climate: How to Achieve a Successful Energy Transition, 1-153. https://doi.org/10.1002/9780470746318

Thomas J. Van Dam, John T. Harvey, Stephen T. Muench, Kurt D. Smith, Mark B. Snyder, Imad L. Al-Qadi, Hasan Ozer, Joep Meijer, Prashant V. Ram, Jeffery R. Roesler, and A. K. (2015). Towards Sustainable Pavement Systems : A Reference Document. FHWAHIF-15-002. 